
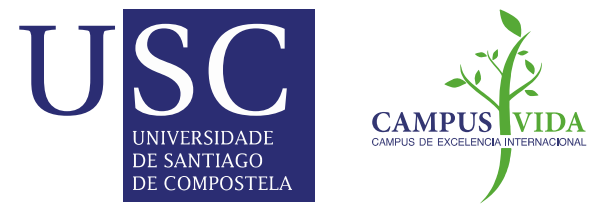

\title{
Towards an environmentally sustainable and healthy Atlantic dietary pattern: Life cycle carbon footprint and nutritional quality
}

Xavier Esteve-Llorens, Carmela Darriba, María Teresa Moreira, Gumersindo Feijoo, Sara GonzálezGarcía

\section{Accepted Mansucript}

\section{How to cite:}

Esteve-Llorens, X., Darriba, C., Moreira, M., Feijoo, G., \& González-García, S. (2019). Towards an environmentally sustainable and healthy Atlantic dietary pattern: Life cycle carbon footprint and nutritional quality. Science Of The Total Environment, 646, 704-715. doi: 10.1016/j.scitotenv.2018.07.264

\section{Copyright information:}

(C) 2018 Elsevier Ltd. This manuscript version is made available under the CC-BY-NC-ND 4.0 license (http://creativecommons.org/licenses/by-nc-nd/4.0/) 

carbon footprint and nutritional quality Xavier Esteve-Llorens, Carmela Darriba, Maria Teresa Moreira, Gumersindo Feijoo and Sara González-García Department of Chemical Engineering, School of Engineering, Universidade de Santiago de Compostela. 15782- Santiago de Compostela, Spain.

*Corresponding author: E-mail address: xavier.esteve.llorens@usc.es

Abstract

Production and consumption of food has a significant effect on climate change. The effect of different consumption habits on the environment should not be under estimated, as there are different studies that mention the environmental impact associated with different foods, especially those of animal origin. The analysis of the Atlantic Diet (AD), as the most common dietary pattern in Northwestern Spain, serves as an example of a diet with a high consumption of local, fresh and seasonal products, home cooking and low-processed foods. The evaluation was carried out by quantifying the carbon footprint following the Life Cycle Analysis methodology and identifying its nutritional quality according to the value of the Nutrient-rich Dietary index (NRD9.3.). According to the main results, the consumption of livestock products and shellfish is responsible for most GHG emissions ( $70 \%$ of the total). The basic ingredients of the $A D$, such as vegetables and legumes, make a relatively minor contribution (with an impact of $30 \%$ of the total) to the total carbon footprint of $3.01 \mathrm{~kg} \mathrm{CO}_{2} \mathrm{eq}$. person ${ }^{-1}$. day ${ }^{-1}$. As regards nutritional quality, AD has a high nutritional score (474), mainly due to the low intake of sodium, added sugars and saturated fats (nutrients to be limited in healthy diets). In general, both the carbon footprint and the nutritional index score are consistent with those of other studies on the Mediterranean diet, which has been recognised as beneficial. Therefore, it can be concluded that the $A D$ may be recommended from a nutritional and environmental point of view, mainly due to the high intake of fish and vegetables. The communication of this valuable environmental and nutritional information to consumers should be taken into account when considering strategic actions for the adoption of healthy and sustainable dietary patterns. 
31 Keywords: Atlantic diet; Daily diet; LCA; Meals; Nutritional value; Sustainable diet 
1. Introduction

Nutrition is a basic human need and access to adequate nutrition depends on numerous social, political and economic factors (Heller et al., 2013). Balanced and complete nutrition affects human health and well-being. The effects of nutritional patterns on overweight, cardiovascular disease and other diet-related health problems are widely known (Coelho et al., 2016; Risku-Norja, 2011). The selection of one type of food versus another entails direct consequences in the supply chain, as well as environmental, economic and social impacts associated with the production process (Cencic and Chingwaru, 2010). In particular, food chains that support diets are linked to environmental issues such as greenhouse gas (GHG) emissions, embedded energy consumption and land use (Irz et al., 2016; Castañé and Antón, 2017). Therefore, environmental pressures on food systems are relevant to public health agendas (Sáez-Almendros et al., 2013).

Food production ranges from agricultural and farming activities to manufacturing, refrigeration, retailing, storage, cooking and final disposal of waste (Garnett, 2011; SáezAlmendros et al., 2013). According to Garnett (2011) and Irz et al. (2016), 15-30\% of total GHG emissions in developed countries are derived from food production, distribution and consumption, and agriculture is responsible for $70-80 \%$ of water consumption (Heller et al., 2013). In this regard, researchers are evaluating the sustainability of food production and eating patterns (Baroni et al., 2007; Donati et al., 2016). According to these studies, lactoovovegetarian or plant-based diets are more environmentally sustainable than those containing resource-intensive products (e.g., meat-rich diets) (Baroni et al., 2007; Risku-Norja, 2011). Of special interest is the development of methodologies to analyse the environmental impact of a product or food system with the most objective approach. (Aleksandrowicz et al., 2016; Duchin, 2005; van de Kamp et al., 2018; Van Kernebeek et al., 2014). The environmental footprints of some diets (e.g., omnivorous, vegetarian, vegan, omega-3 fatty acids enriched) have been quantified according to the Life Cycle Assessment - LCA methodology (Pimentel and Pimentel, 2003; Coelho et al., 2016). In this sense, numerous studies can be found in the literature in which the relationship between European diets, nutritional quality and environmental aspects are evaluated in detail (Aleksandrowicz et al., 2016; Duchin, 2005; van de Kamp et al., 2018; Van Kernebeek et al., 2014). 
Several studies can be found in the literature where the food trends of Swedish

63 homemade menus were analysed proposing dietary guidelines, with special attention to organic

64 food (Carlsson-Kanyama et al., 2003; Carlsson-Kanyama and Faist, 2000; Carlsson-Kanyama

65 and Linden, 2001). In these studies, the energy needs throughout the life cycle of Swedish diets

66 were estimated with the aim of planning home-cooked meals that were nutritionally rich but

67 included products that were less energy-intensive.

68 Jungbluth et al. (2000) proposed a simplified LCA approach to assess consumption 69 patterns in Switzerland with the aim of identifying environmental-friendly decisions. The authors 70 propose different actions to reduce environmental impacts. Therefore, it was proposed to 71 reduce meat consumption and demand for airborne products as well as to promote the consumption of organic products.

73 The effect of Dutch consumption patterns on agricultural land needs was also assessed in detail (Gerbens-Leenes et al., 2002; Gerbens-Leenes and Nonhebel, 2002). According to these studies, large differences in land requirements for food production were identified not only in the Netherlands, but also for other European countries. A hypothetical analysis of a wheatbased diet would require up to six times less soil compared to a meat-rich diet.

Finally, Van Kernebeek et al. (2014) addressed the question of whether plant-based diets have lower environmental impact than those with a significant contribution of food with animal origin, but taking into consideration nutritional quality. To this end, a review of more than fifty peer-reviewed studies was conducted. The results showed that diets with higher percentages of food products of animal origin could be associated with higher GHG emissions and land use requirements, but these results were variable depending on the functional unit considered. Special mention was made of the need to assess the overall nutritional quality of a diet and the recommended levels of protein intake as particularly relevant elements to be taken into account when comparing dietary patterns.

The most recent literature contains numerous references on the selection of the most appropriate functional units for the calculation of the environmental impacts of food consumption patterns. The energy content (daily calories), protein or fat content of diets are some of the most common examples (Pimentel and Pimentel, 2003; Heller et al., 2013). Moreover, profiles per serving or per potential economic value are also available (Heller et al., 2013; Van Der Werf and 
Salou, 2015). However, nutritional value must be the crucial element of reference for the definition of a healthy diet. Nutrient-based recommendations should be specifically considered

94 in the search for and promotion of a sustainable dietary pattern that meets these values 95 (Smedman et al., 2010; Heller et al., 2013). The high consumption of fruits, vegetables and whole grains in the diet is closely related to the reduction of the risk of developing chronic diseases such as cancer and cardiovascular diseases, which are the main causes of death in industrialized countries (Cencic and Chingwaru, 2010). Based on this type of food, healthier and more fruit and vegetable-rich diets have been identified in southern countries. In contrast, northern countries have diets rich in animal fats and food products of animal origin. It is interesting to identify different social contexts and cultural values in relation to food (Nordström et al., 2013). While food is an individual issue in northern countries, society in central and southern Europe associates food with the social dimension of sharing a meal (Cencic and Chingwaru, 2010).

Spain is one of the European countries with the lowest mortality rates for ischaemic heart disease. Within the country, regional differences have been identified in this regard. In fact, variations have been reported to be up to $40 \%$ lower than the average in northern cities

108 (Medrano et al., 2012). The traditional Atlantic diet is a common dietary pattern in northern Portugal and Galicia (northwest Spain), culturally and climatically similar areas and has been

110 associated with a lower likelihood of myocardial infarction and good metabolic health (Calvo-

111 Malvar et al., 2016; Atlantic Diet Foundation ${ }^{1}$ ). The Atlantic diet is characterised by an abundant

112 consumption of plant-based products, as well as local and fresh products (seasonal food) with

113 reduced cooking time. The consumption of meat (mainly beef and pork) and eggs is reasonable

114 and olive oil is considered as the main source of fat for cooking and seasoning (Calvo-Malvar et

115 al., 2016; Charro et al., 2006). Recently, it has been rated as a world reference for a healthy diet

116 (Vaz Velho et al., 2016). The Atlantic diet differs from the Mediterranean - the most popular in 117 southern Spain, in terms of increased consumption of fish, red meat, pork, milk, potatoes, fruit, 118 vegetables and olive oil (Guallar-Castillón et al., 2013), which implies significant changes in 119 nutrients and functional components. However, both of them can be taken as examples of 120 healthy diet (Tojo and Leis, 2009; Sáez-Almendros et al., 2013).

\footnotetext{
${ }^{1}$ https://www.fundaciondietatlantica.com/eng/index.php (accessed July, 2018)
} 
This study has a twofold objective: to quantify the carbon footprint of the Atlantic diet through a LCA approach associated with the production of the different foods that make up this

123 diet, while identifying its nutritional quality. The recommended Galician dietary pattern and the corresponding intake data have been taken into account. The main causes of GHG emissions will be highlighted to identify options for improvement.

\section{Materials and methods}

\subsection{Weekly menu based on the Atlantic diet}

The concept of the Atlantic diet dates back to the traditional menus of Galician gastronomy.

With the social awareness of a healthy diet, the benefits of this dietary pattern are reflected in a recent study (Vaz Velho et al., 2016) (see Figure 1). It is characterised by i) a high intake of seasonal foods, vegetables, fruits, potatoes, bread and cereals, chestnut, whole nuts, legumes and honey, fish, molluscs and crustaceans; ii) a moderate consumption of milk, cheese, meat (beef and pork), eggs and iii) cooking methods based on boiling, stewing, grilling and roasting.

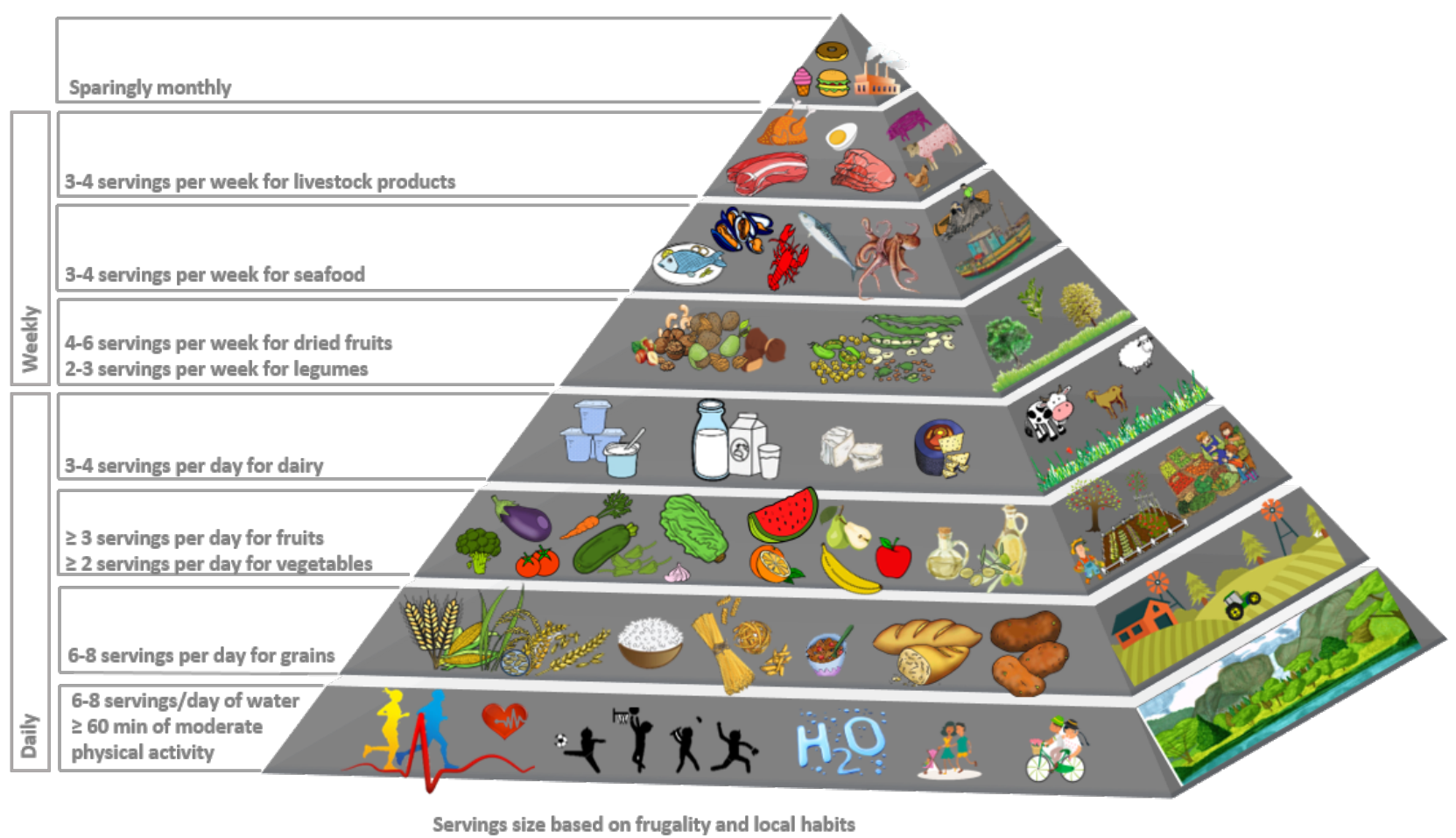


Figure 1. Atlantic diet pyramid. The base and the top of the pyramid include the foodstuffs

140 that must be daily consumed or occasionally consumed, respectively.

142 Although studies can be found in the literature that consider individual meals, daily or 143 annual diets (Van Kernebeek et al., 2014), a weekly diet has been considered for analysis, as it 144 may facilitate comparison with other types of dietary patterns. Following the recommendation of 145 Tojo and Leis (2009), a weekly diet has been designed- displayed in Table 1 - consisting of 146 seven daily menus (daily diets) divided in five meals (breakfast, mid-morning snack, lunch,

147 afternoon snack and dinner) has been designed, as similar as possible to the recommended

148 Galician eating habits (Xunta de Galicia, 2013). This weekly diet is based on 2,100 kcal and

149 corresponds to the energy needs of an active Spanish adult woman (regular physical activity)

150 according to FAO (2014).

152 Table 1. Atlantic diet based weekly menus designed for this study taking into account the 153 recommended servings of the different food groups. The daily diets have been adjusted to a recommended energy intake of $2,100 \mathrm{kcal}$.

Daily diet

\begin{tabular}{|c|c|c|c|c|c|c|c|}
\hline & \\
\hline & Monday & Tuesday & Wednesday & Thursday & Friday & Saturday & Sunday \\
\hline Breakfast & $\begin{array}{l}\text { Glass of } \\
\text { milk and } \\
\text { bread with } \\
\text { tomato }\end{array}$ & $\begin{array}{l}\text { Glass of } \\
\text { milk. } \\
\text { cereals. } \\
\text { nectarine }\end{array}$ & $\begin{array}{c}\text { Glass of } \\
\text { milk. } \\
\text { Wholemeal } \\
\text { bread. } \\
\text { orange }\end{array}$ & $\begin{array}{l}\text { Glass of } \\
\text { milk. } \\
\text { wholemeal } \\
\text { cereals. } \\
\text { nectarine } \\
\end{array}$ & $\begin{array}{c}\text { Glass of } \\
\text { milk. } \\
\text { wholemeal } \\
\text { bread. } \\
\text { orange } \\
\end{array}$ & $\begin{array}{l}\text { Curd with } \\
\text { honey. } \\
\text { wholemeal } \\
\text { bread }\end{array}$ & $\begin{array}{c}\text { Glass of } \\
\text { milk. bread. } \\
\text { peach }\end{array}$ \\
\hline $\begin{array}{l}\text { Mid-morning } \\
\text { Snack }\end{array}$ & Orange & Yogurt & Yogurt & Infusion & Apple & Kiwi & Pear \\
\hline Lunch & $\begin{array}{c}\text { Steamed } \\
\text { cockles. } \\
\text { vegetable } \\
\text { cannelloni. } \\
\text { nectarine. } \\
\text { bread }\end{array}$ & $\begin{array}{l}\text { Vegetables } \\
\text { and fruits } \\
\text { salad. } \\
\text { black rice } \\
\text { with } \\
\text { cuttlefish. } \\
\text { bread } \\
\end{array}$ & $\begin{array}{l}\text { Carrot salad. } \\
\text { Galician } \\
\text { style conger. } \\
\text { two figs. } \\
\text { bread }\end{array}$ & $\begin{array}{l}\text { Mackerel } \\
\text { with } \\
\text { potatoes and } \\
\text { roasted } \\
\text { peppers. } \\
\text { watermelon. } \\
\text { bread }\end{array}$ & $\begin{array}{l}\text { Octopus } \\
\text { with } \\
\text { potatoes. } \\
\text { salad. curd } \\
\text { with honey. } \\
\text { bread }\end{array}$ & $\begin{array}{c}\text { Cod } \\
\text { croquettes. } \\
\text { vegetable } \\
\text { stew. } \\
\text { tangerine. } \\
\text { bread }\end{array}$ & $\begin{array}{l}\text { Padron } \\
\text { peppers. } \\
\text { roast beef } \\
\text { with } \\
\text { potatoes }\end{array}$ \\
\hline $\begin{array}{l}\text { Afternoon } \\
\text { snack }\end{array}$ & Banana & Melon & Banana & Peach & Banana & Yogurt & Nectarine \\
\hline Dinner & $\begin{array}{l}\text { Grilled } \\
\text { beef steak } \\
\text { with rice. } \\
\text { bread }\end{array}$ & $\begin{array}{l}\text { Grilled } \\
\text { pork steak. } \\
\text { steamed } \\
\text { Brussels } \\
\text { sprouts. } \\
\text { pear. } \\
\text { bread } \\
\end{array}$ & $\begin{array}{l}\text { Pumpkin } \\
\text { cream. pear. } \\
\text { bread }\end{array}$ & $\begin{array}{l}\text { Pasta salad. } \\
\text { fresh } \\
\text { cheese. } \\
\text { bread }\end{array}$ & $\begin{array}{c}\text { Grilled } \\
\text { beef steak } \\
\text { with rice } \\
\text { and } \\
\text { steamed } \\
\text { vegetables }\end{array}$ & $\begin{array}{l}\text { Chicken } \\
\text { steak with } \\
\text { pasta and } \\
\text { mushrooms. } \\
\text { grapes. } \\
\text { bread }\end{array}$ & $\begin{array}{l}\text { Scrambled } \\
\text { eggs with } \\
\text { mushrooms } \\
\text { and pasta }\end{array}$ \\
\hline $\begin{array}{l}\text { Total energy } \\
\text { intake }\end{array}$ & $2,124 \mathrm{kcal}$ & $2,101 \mathrm{kcal}$ & $2,295 \mathrm{kcal}$ & $2,140 \mathrm{kcal}$ & $2,051 \mathrm{kcal}$ & $2,189 \mathrm{kcal}$ & $2,097 \mathrm{kcal}$ \\
\hline
\end{tabular}


157 Recommended servings of different food groups have been considered for evaluation. Table 2

158 shows the frequency servings for the Atlantic dietary pattern. Although the specific composition

159 of the diet changes with age and sex, this level of uncertainty can be assumed for the 160 estimation of the carbon footprint.

161

162 Table 2. Main recommendations of servings (s) frequency for each food group for the Atlantic 163 Diet adapted from Velho et al. (2016).

164

165

\begin{tabular}{lc}
\hline Food group & Servings frequency \\
\hline Cereals/Grains & $6-8 \mathrm{~s} \cdot$ day $^{-1}$ \\
Fruits & 3s or more $\cdot$ day $^{-1}$ \\
Vegetables & 2s or more $\cdot$ day $^{-1}$ \\
Olive oil & $3-4 s \cdot$ day $^{-1}$ \\
Dairy products & $3-4 s \cdot$ day $^{-1}$ \\
Dried fruits & $4-6 s \cdot$ week $^{-1}$ \\
Legumes & $2-3 s \cdot$ week $^{-1}$ \\
Seafood & $3-4 s \cdot$ week $^{-1}$ \\
Meat & $3-4 s \cdot$ week $^{-1}$ \\
Eggs & $3-4 s \cdot$ week $^{-1}$ \\
Sweets & Sparingly monthly \\
\hline
\end{tabular}

166

2.2. Estimation of the Atlantic diet nutrient composite score

One of the main objectives of this study is to analyse the nutritional quality of the Atlantic diet to identify whether this dietary pattern meets healthy parameters. It is well known that consumers are advised to look for nutrient-rich foods rather than discretionary calories. Taking into account the main recommendations from Van Kernebeek et al. (2014), the nutrient intake associated with one single meal cannot be used to assess the nutritional quality of a daily diet.

172 Therefore, the nutritional quality has been analysed through daily menus. This perspective will

173 facilitate comparison with alternative dietary patterns. The Nutrient Rich Food (NRF9.3) score

174 (Drewnowski, 2009; Fulgoni et al., 2009) is considered the cornerstone of a dietary guidance 175 approach to healthy eating. However, the Nutrient Rich Diet (NRD9.3) score was considered in 
176 this study to estimate the nutritional quality of the Atlantic diet. This method has been proposed

177 by Van Kernebeek et al. (2014) as a modification of the NRF9.3 index as it is not scaled to

178 energy intake (the former refers to $100 \mathrm{kcal}$ of a given food).

179 A total of nine nutrients to encourage (protein, fibre, calcium, iron, magnesium, potassium,

180 vitamin A, vitamin C, vitamin E) and three nutrients to limit (sodium, saturated fat and added

181 sugar) have been considered for the estimation of the score (see Equation 1). In this sense, the

182 greater the amount of nutrients ingested to encourage and the smaller the amount of nutrients

183 to limit, the higher the NRD 9.3 index is. Nevertheless, when the 9 nutrients to encourage

184 exceed the Recommended Daily Value (RDV), they are capped to this previous value, in order

185 to avoid overestimation caused by overconsumption.

186

$$
N R D 9.3=\left(\sum_{i=1}^{i=9} \frac{\text { nutrient }_{\text {i capped }}}{R D V_{i}}-\sum_{k=1}^{k=3} \frac{\text { nutrient }_{k}}{R D V_{k}}\right) * 100
$$

Equation 1

187 Table 3 shows the average daily nutrient intake corresponding to a typical Atlantic diet

188 (Fundación Española de la Nutrición, 2004), as well as those recommended for each nutrient to

189 be promoted and the maximum for each nutrient to be limited, taking into account health

190 recommendations (Castañé and Antón, 2017).

191

192 Table 3. Recommended nutrients daily intake (RDV) and daily average nutrients composition

193 for the Atlantic Diet (AD).

194

\begin{tabular}{|c|c|c|c|c|c|c|c|c|c|c|c|c|}
\hline & \multicolumn{9}{|c|}{ Boosting nutrients } & \multicolumn{3}{|c|}{ Limiting nutrients } \\
\hline & Protein & Fiber & Vit A & Vit C & Vit E & $\mathrm{Ca}$ & $\mathrm{Fe}$ & $\mathbf{K}$ & $\mathrm{Mg}$ & $\begin{array}{l}\text { Saturate } \\
\text { d fat }\end{array}$ & $\begin{array}{l}\text { Added } \\
\text { sugar }\end{array}$ & $\mathrm{Na}$ \\
\hline & g & g & $\mu \mathrm{g}$ & $\mathrm{mg}$ & $\mathrm{mg}$ & g & $\mathrm{mg}$ & g & $\mathrm{mg}$ & g & g & $g$ \\
\hline RDV $^{1}$ & 50 & 25 & $700-3000$ & $60-2000$ & $20-1000$ & $1.0-2.5$ & $18-45$ & 3.5 & 400 & 20 & 50 & $1.5-2.4$ \\
\hline$A D^{2}$ & 91 & 21 & 1404 & 179 & 13 & 1.01 & 13.8 & 3.5 & 237 & 28 & 2.0 & 1.9 \\
\hline
\end{tabular}

195

196

The NRD9.3 score has been estimated for each daily diet previously designed and

197 reported in Table 1. In addition, an average score has been calculated with these specific

198 indexes with the aim of obtaining a final dietary quality score for the Atlantic diet. This average

199 score has been benchmarked with others available in the literature (Van Kernebeek et al., 2014)

200 to identify how it is ranked in terms of nutritional quality. Finally, the nutritional quality score has 
been supplemented with the assessment of individual nutrient scores, taking into account the 12 nutrients mentioned above. For this purpose, the Nutrient Rich (NR) index for each nutrient is calculated according to the method proposed by Van Kernebeek et al. (2014). This index reports the nutrient intake in relation to the RDV.

\subsection{Estimating the Carbon Footprint of the Atlantic diet}

The relevance of food products to the environmental pressure of society-related activities is truly outstanding (Garnett, 2011; Sonesson et al., 2005; Irz et al., 2016). Within environmental pressures, GHG emissions receive special attention (Garnett, 2011). There are multiple studies focused on the environmental profiles of individual food products such as onion (Aguilera et al.,

211 2015), yogurt (González-García et al., 2013a), cheese (Berlin, 2002; González-García et al., 212 2013b), canned tuna (Hospido and Tyedmers, 2005), bread (Andersson and Ohlsson, 1999), 213 cod fillets (Ziegler et al., 2003), pork (Noya et al., 2017) or tomato ketchup (Andersson et al., 214 1998). However, studies that focus on environmental profiles related to dietary patterns have 215 started to attract interest in recent years (Van Kernebeek et al., 2014; Coelho et al., 2016; 216 Pernollet et al., 2016). According to the literature (Carlsson-Kanyama and González, 2009;

217 Committee on Climate Change, 2010; Scarborough et al., 2014), GHG emissions vary considerably between food products and also depends on the efficiency of the production chain.

For the estimation of the carbon footprint of each daily diet that constitutes the weekly menu of the recommended Atlantic diet, the Life Cycle Analysis (LCA) approach, a standardized methodology for the systematic assessment of the environmental burdens of a product or service system at all stages of its life cycle, has been taken into account (ISO 14040, 2006).

223 LCA has increased its application in food analysis in recent years and has been considered as a potential assessment method for environmental profiles of food products and dietary patterns

225 (Goldstein et al., 2016). In line with other authors (Carlsson-Kanyama and Faist, 2000; Duchin, 2005; Jungbluth et al., 2000), a simplified LCA has been carried out considering only the most

227 important stages in terms of resource consumption (from food production to consumption) and avoiding other relevant minor stages such as the production of packaging materials or waste management, mostly due to the lack of detailed data for some foodstuffs. 
Therefore, this study addresses the estimation of GHG emissions in the Atlantic diet considering the recommended dietary patterns with the aim of answering the question "Is the Atlantic diet a healthy and environmentally sustainable diet?".

\subsection{Functional unit}

LCA attempts to quantify the material and energy flows throughout the life cycle of the system under analysis, in this case, daily menus of the Atlantic diet. Thus, a functional unit is required to provide a common basis for comparison and to report the corresponding carbon footprint. Although different functional units have been considered in related studies the recommended 2,100 kcal per day supply of food, excluding non-dairy beverages, has been considered (FAO, 2014), which is in line with the one selected in other relevant studies available in the literature (Sáez-Almendros et al., 2013; Scarborough et al., 2014) and allows comparison between the results achieved. In this functional unit, the primary function of the daily diet, i.e. the supply of energy and nutrients for an adult woman, is fulfilled. However, it is important to note that consuming $2,100 \mathrm{kcal}$ per day does not imply a nutritionally adequate diet. For this reason, the assessment of the nutritional score (NRF9.3) is selected to complete this study and give an answer to the former question.

2.5. Scope of the Atlantic diet analysis

The carbon footprint for each daily diet reported in Table 1 will be estimated according to a cradle-to-mouth perspective (see Figure 2). The system analysed has therefore been divided into three stages:

- Food production stage, i.e. production of the different food ingredients that make up each daily menu (breakfast, mid-morning snack, lunch, afternoon snack and dinner). At this stage, a "cradle-to-farm or industry" approach was considered, depending on the food product. A detailed description by food product is given in the Supplementary material (SM Table 1). refrigeration (if necessary). 
- Transport stage, i.e., the distribution of the different food products from the factory or

260 farm gate to the retailer, as well as from the retailer to households.

261 The carbon footprint of the household stage has been calculated taking into account three main cooking processes, such as boiling, frying, and baking as well as home storage in refrigerators.

263 The abundance of fresh products in the Atlantic Diet makes large cooking processes unnecessary (Tojo and Leis, 2009; Vaz Velho et al., 2016). For this reason, it has been assumed that only one of the three cooking methods is used for each serving when necessary, in line with Castañé and Antón (2017). According to Sonesson and colleagues (Sonesson et al., 2003), the carbon footprint associated with the cooking process is expected to derive mainly from the energy consumption of household appliances. Regarding home storage, it has been computed the average electricity consumption reported by Muñoz et al. (2010) associated with the use of a combined refrigerator and a freezer. According to that study, electricity requirements correspond with $0.52 \mathrm{kWh}$ per person and day.

272

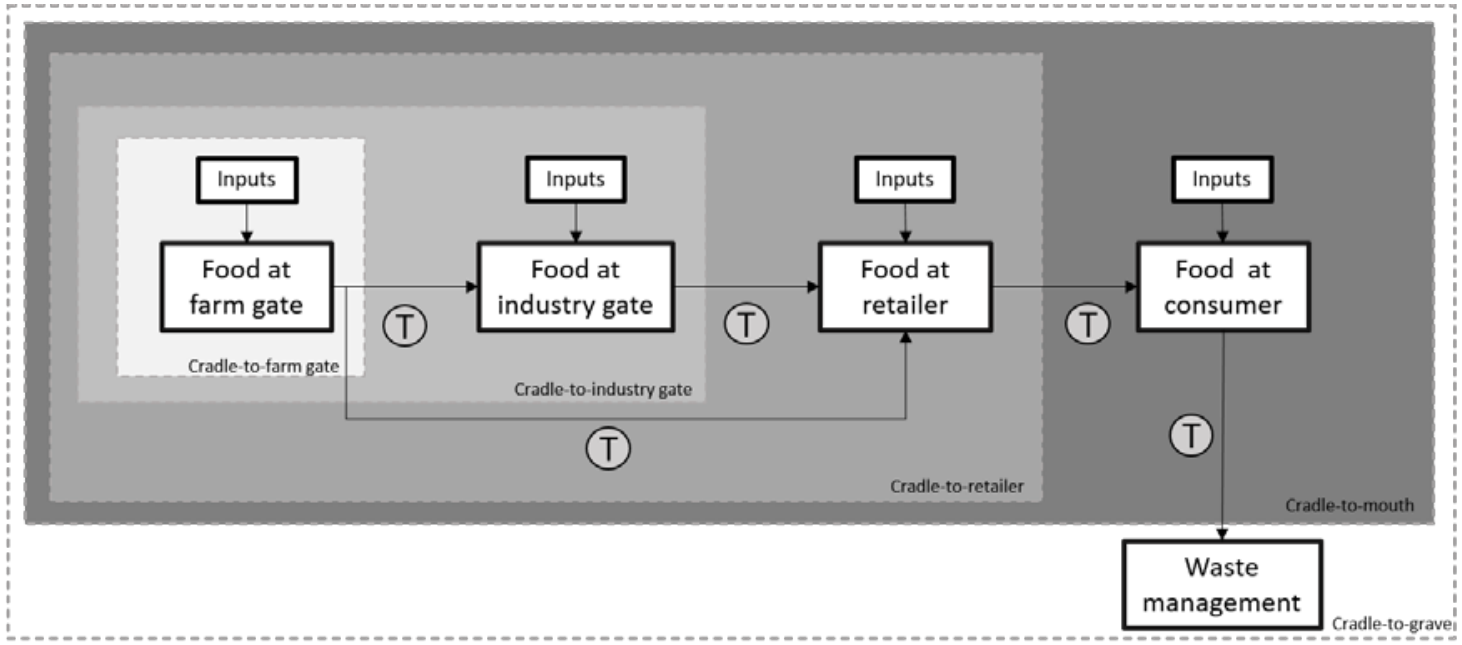

(T) = Transport

274 Figure 2. System boundaries considered in the analysis of the carbon footprint associated to the recommended Atlantic dietary pattern (cradle-to-mouth) as well as alternative limits available in the literature. 
As far as transport activities are concerned, Euro 5 diesel freight lorries ( $>32$ tons) have been considered for transport from the factory/farm gate to retailers for the food produced in 282 Spain. Thus, average distribution distances of $400 \mathrm{~km}$ and $60 \mathrm{~km}$ (on average) have been estimated for distribution from outside and within Galicia respectively. For products manufactured outside Spain, an average distance by ship and lorry from their country of origin to Galicia has been considered. In all the situations, refrigerated transport has been considered when necessary.

Moreover, the transport from retailers to households has also been taken into account despite their negligible contribution reported in other works (Castañé and Antón, 2017). According to Sonesson et al. (2005), consumers go shopping once a week, mainly on foot (70\%) rather than by car or public transport (30\%). In line with González-García et al. (2013), an average distance of about $10 \mathrm{~km}$ has been established between the retail trade and households. In our study, we have excluded from the analysis those inputs that can be assumed to change to a lesser extent between diets such as cleaning products, kitchen utensils, cutlery and dishes, following the recommendations of Pernollet et al (2016).

Data quality for the estimation of carbon footprint of food products

A sample of 67 food items in the shopping basket have been grouped into 9 different categories, as shown in the Supplementary material (SM Table1) (fruits, vegetables, legumes, grains, dairy, meat, fish/crustaceans, eggs, olive oil and sweets). The origin of products has been selected on the basis of their most common origin, data availability and, when possible, the consumption of local and seasonal products.

With regard to the data sources considered for the estimation of the GHG emissions associated with each food product, 32 LCA studies focused on the production stage have been considered. The system boundaries in most foods range from cradle-to-farm gate, as shown in

304 the Supplementary material (SM Table 1). However, in certain products the system boundaries cover the perspectives of cradle-to-retailer or even cradle-to-grave, as in the case of mushrooms (Leiva et al., 2015) and yoghurt (González-García et al., 2013a), respectively. Therefore, in these cases the corresponding GHG emissions have been discarded to be consistent with the system boundaries established in our analysis at the production stage. In other cases, some food products have been assimilated to others because of the lack of 
310 information on their production stages and the similarity between production chains. These

311 hypotheses have been taken into account in the case of nectarine (peach), pumpkin (melon) as

312 well as leek (onion). Food products excluded from the analysis include spices and condiments

313 such as salt. Alcoholic beverages, soft drinks, coffee and infusions have also been excluded

314 from the analysis in line with related studies (Castañé and Antón, 2017; Van Kernebeek et al., 315 2014).

316 The Ecoinvent ${ }^{\circledR}$ v3.2 database has been considered for the estimation of GHG emissions 317 (carbon footprint) linked to background processes (e.g., production of electricity requirements)

318 and for transport activities considering the characterisation factors from Intergovernmental

319 Panel on Climate Change (IPCC).

3. Results and discussion

3.1. Nutritional quality of Atlantic daily diets

Table 4 shows the nutrient intake for each dietary daily scenario, as well as the average value of the Atlantic dietary pattern. In accordance with the considerations assumed, all diets have been developed to cover all nutritional needs These values are the result of considering the complete menus together with the corresponding amount of each food ingredient and its nutritional composition as can be seen in Tables 2 to 8 of the SM. A detailed description of the daily diet and the food included is given in Table A1 of the Appendix.

329

Table 4. Daily average boosting/limiting nutrients intake for the Atlantic diet based weekly menus designed for assessment in this study.

\begin{tabular}{|c|c|c|c|c|c|c|c|c|c|c|c|c|}
\hline & \multicolumn{9}{|c|}{ Boosting nutrients } & \multicolumn{3}{|c|}{ Limiting nutrients } \\
\hline & Protein & Fiber & VitA & VitC & VitE & $\mathrm{Ca}$ & $\mathrm{Fe}$ & $\mathbf{K}$ & $\mathrm{Mg}$ & $\begin{array}{l}\text { Saturated } \\
\text { fat }\end{array}$ & $\begin{array}{l}\text { Added } \\
\text { sugar }\end{array}$ & $\mathrm{Na}$ \\
\hline & $g$ & $g$ & $\mu g$ & $\mathrm{mg}$ & $\mathrm{mg}$ & $\mathrm{mg}$ & $\mathrm{mg}$ & $\mathrm{mg}$ & $\mathrm{mg}$ & $g$ & $g$ & $g$ \\
\hline Monday & 120.4 & 35.5 & 1692 & 339 & 11 & 1436 & 73 & 4578 & 487 & 24.2 & 1.9 & 1.51 \\
\hline Tuesday & 85.5 & 43.9 & 635 & 203 & 11.9 & 848 & 21 & 5234 & 483 & 14.3 & 2.3 & 1.50 \\
\hline Wednesday & 123.0 & 36.8 & 734 & 250 & 10 & 1105 & 21 & 4948 & 407 & 23.6 & 1.8 & 1.33 \\
\hline Thursday & 91.0 & 41.0 & 1609 & 463 & 13 & 1152 & 66 & 4948 & 505 & 19.9 & 2.3 & 1.50 \\
\hline Friday & 88.7 & 46.6 & 2108 & 391 & 12 & 1114 & 19 & 5071 & 425 & 16.5 & 1.8 & 1.31 \\
\hline
\end{tabular}




\begin{tabular}{lcccccccccc|cc}
\hline Saturday & 88.7 & 39.2 & 1680 & 309 & 11 & 1009 & 17 & 4479 & 345 & 18.1 & 2.3 & 1.56 \\
\hline Sunday & 111.0 & 36.3 & 1680 & 289 & 92 & 921 & 18 & 5308 & 393 & 18.8 & 1.9 & 1.46 \\
\hline $\begin{array}{l}\text { Daily } \\
\text { average }\end{array}$ & 101.2 & 39.9 & 1448 & 321 & 23. & 1084 & 33 & 4938 & 435 & 19.3 & 2.0 & 1.45 \\
\hline
\end{tabular}

As shown in Table 4, the average daily diet reports an intake of numerous nutrients to be encouraged (i.e., protein, fibre, potassium and magnesium) higher than the values recommended in Table 3, as well as the average values corresponding to the Atlantic diet reported in the literature (Fundación Española de la Nutrición, 2004).

The high protein intake observed is related to the outstanding consumption of fish and moderate consumption of meat (mainly beef and pork). All designed daily diets exceed the recommended daily protein intake value of $50 \mathrm{~g}$ (up to 2.5 times).

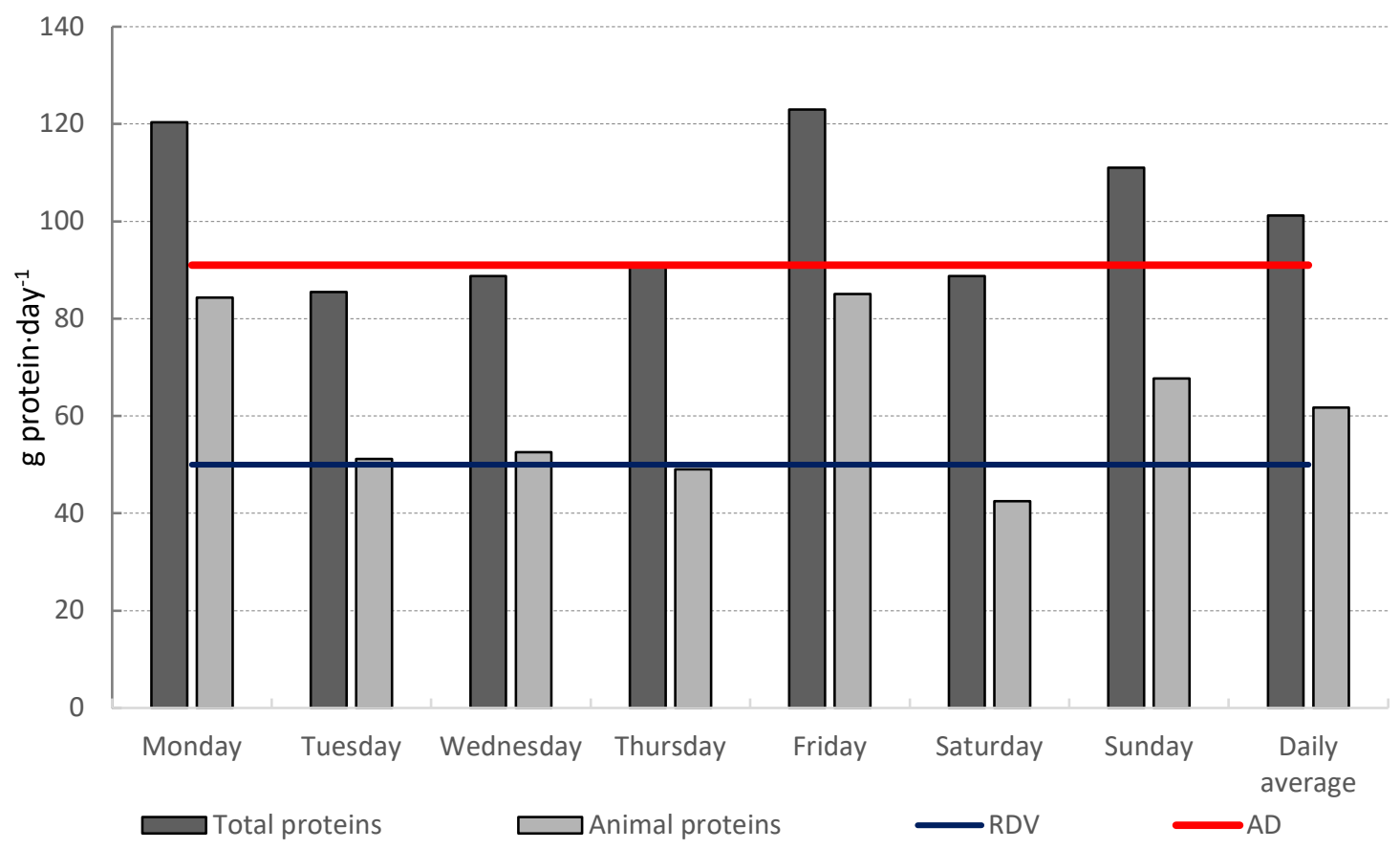

Figure 3. Total protein and animal based protein ingestion per daily diet designed 343 under the Atlantic dietary patterns $\left(\mathrm{g} \cdot\right.$ day $\left.^{-1}\right)$. RDV - Recommended Daily Value $\left(\mathrm{g} \cdot\right.$ day $\left.^{-1}\right)$. AD 344 Established average daily protein intake under Atlantic dietary pattern $\left(\mathrm{g} \cdot \mathrm{day}^{-1}\right)$.

Figure 3 represents the daily protein intake for each designed daily diet, together the average dietary value and the recommended daily value suggested by Fundación Española de

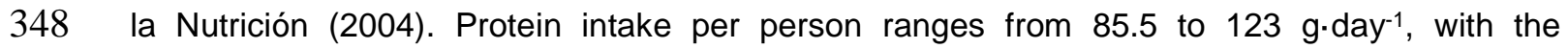
percentage of animal protein in relation to total dietary protein varying between $48 \%$ and $70 \%$. 
350 In line with Van Kernebeek et al. (2014), protein intake is positively associated with AP\%.

351 According to the intrinsic characteristics of the Atlantic diet, protein intake comes mainly from

352 seafood and meat, as well as $26 \%$ (on average) from dairy products such as milk, yoghurt and 353 cheese.

354 Fibre intake can be almost double the recommended value, mainly due to the high intake of fruits, vegetables (e.g., potatoes) and cereals (bread). This high intake of seasonable products also leads to a high dose of potassium. As for magnesium, the remarkable consumption of blue fish (e.g., mackerel) and molluscs (e.g., cockles) along with cereals affects the intake ratio. calcium and iron, the amount consumed is within the recommended range. It can be associated with the consumption of a nutrient-enriched product, such as carrots (common as side dish) for vitamin A, pepper (the food product with the highest vitamin $\mathrm{C}$ content and a common spice ingredient) and vitamin E, molluscs and dairy products for calcium and fish and molluscs for iron.

For nutrients to limit (saturated fat, added sugar and sodium), their intake is below the recommended limits. The consumption of olive oil and dairy products such as cheese is associated with consumption of saturated fats (both food groups present a serving frequency of 3-4 s.day ${ }^{-1}$ ). For added sugar, the intake is around $4 \%$ of the maximum recommended value. In designed daily diets, it is associated with the consumption of bread and whole grain cereals. The consumption of bread is a characteristic of the Atlantic diet, being greater than in other types of diets such as the Mediterranean. The outstanding presence of fish (mackerel, cuttlefish,...), bread and meat is mainly responsible for sodium in the diet. Moreover, the Atlantic diet is characterised by a high intake of unsaturated fatty acids, which makes it one of the highest in the world (Fundación Española de la Nutrición, 2004).

Just as a remark, potatoes are a basic food ingredient in the Atlantic diet, unlike other dietary patterns such as Mediterranean or even vegan diets. It is considered an important source of complex carbohydrates, fibre, minerals, vitamins and water.

Another point to take into account is the notable difference between the intake of nutrients

378 (mainly fibre, vitamin C, vitamin E, iron, potassium, magnesium and added sugar) estimated for 379 the daily diets designed and those reported in the literature for the Atlantic diet (Fundación 
Española de la Nutrición, 2004). Dietary scenarios depend on individual meals, which are affected by factors such as local conditions, seasonal food, gender and even the economic profile of the family. The relationship between these factors and the nutrients intake could be further explored, but it is beyond the scope of this study. (corresponding to the diet proposed for Tuesday) to 525 (corresponding to the diet proposed for Thursday), as shown in Figure 4. These values are in line with others reported in the literature ranging from 260 to 666 , corresponding to other different types of dietary patterns (Nordic, Finish, Indian, English, Mediterranean, vegan...) (Collins and Fairchild, 2007; Risku-Norja et al., 2008; Pathak et al., 2010; Saxe et al., 2012).

390

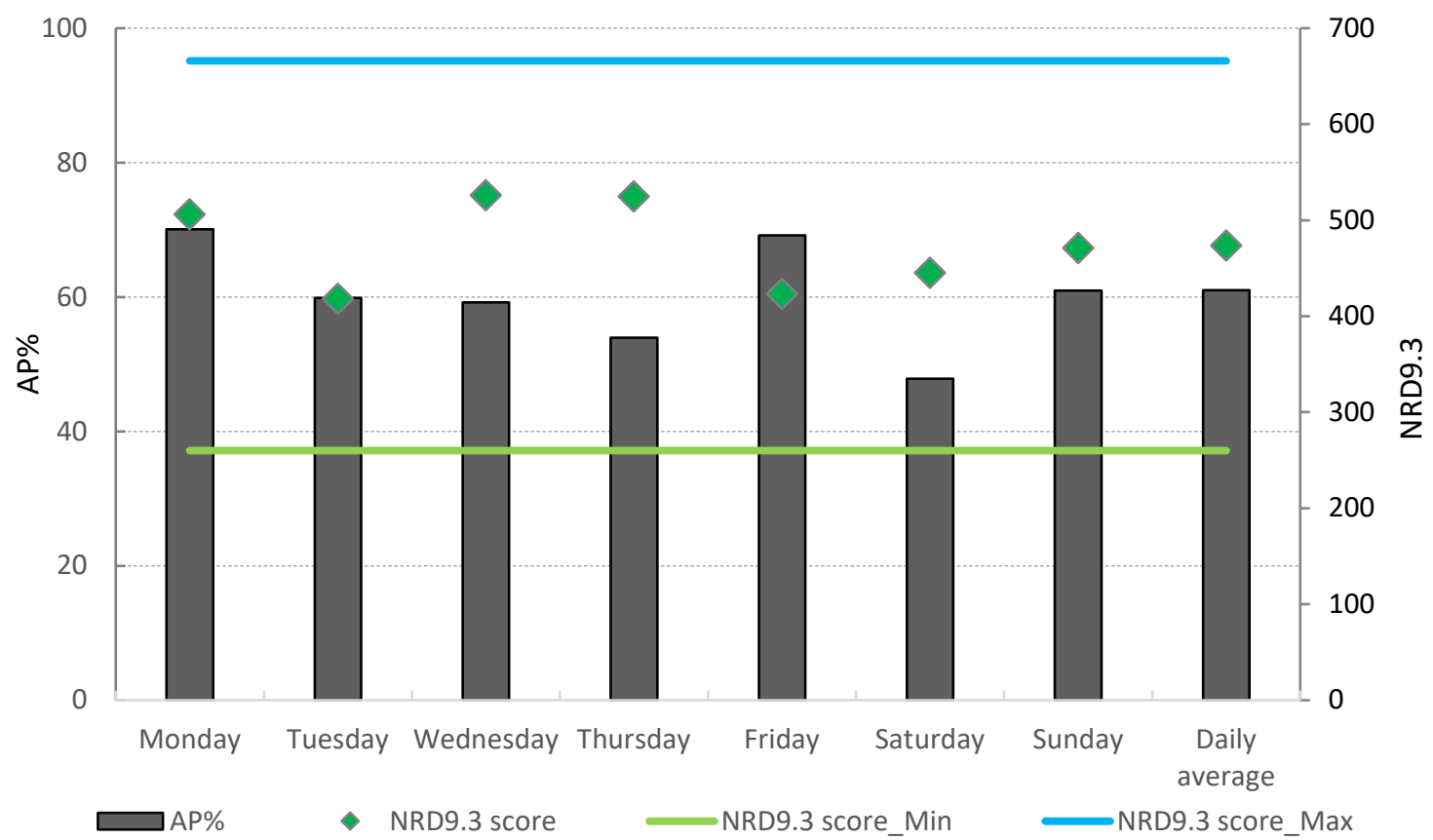

392 Figure 4. NRD9.3 scores and AP\% (ratio of animal based protein and total dietary protein) for each diet that constitutes the designed weekly menu. Minimum (Min) and maximum (Max) NRD9.3 score values found in the literature are also displayed. Numbers on the left-y-axis represent the AP\% (in \%). Numbers on the right-y-axis represent the NRD9.3 scores.

The specific characteristics of each particular type of diet are responsible for the wide range of values in the NRD9.3 index. Moreover, this index is also affected by the above-mentioned parameters (nutrients to encourage/limit as well as RDV) since its estimation is directly dependent on nutrient intake. According to the literature (Van Kernebeek et al., 2014), the relationship between the NRD9.3 score and the percentage of animal protein can vary 
402 considerably between studies and there is no a general trend. Risku-Norja et al. (2009) and 403 Gerbens-Leenes and Nonhebel (2002) identified a reduction in the NRD9.3 score with an 404 increase in the ratio of animal protein to total protein consumed. In contrast, other authors 405 (Collins and Fairchild, 2007; Saxe et al., 2012) identified the opposite trend. Thus, this effect 406 has been also analysed in this study considering the different daily diets proposed for analysis 407 along with the average. The results in Figure 4 do not show a clear correlation. Some daily diet 408 scenarios have a downward trend, while others have an upward trend in the NRD9.3 score, with 409 an increase in the ratio of animal protein to total daily protein consumed (AP\%).

$410 \quad$ Van Kernebeek et al. (2014) proposed an association between both parameters (NRD9.3 411 and $\mathrm{AP} \%$ ) considering the results reported in the literature and concluded that the NRD9.3 412 score is negatively associated with the protein ratio. With this consideration in mind, Figure 5 413 shows the association between the NRD9.3 score and the AP\% for the weekly diet proposed 414 here. In addition, the NRD9.3 scores corresponding to these AP\% values have also been 415 estimated considering the correlation proposed by Van Kernebeek et al. (2014). The estimated 416 values are 1.1-1.3 times higher than those calculated for our weekly menu. Variations in nutrient 417 composition and dietary characteristics are responsible for these differences. However, in line 418 with Van Kernebeek et al. (2014), the same behaviour can be observed and the score is 419 negatively associated with the AP\%. In this sense, these results can be useful and provide 420 information to both consumers and policy-makers to achieve healthier food choices in the 421 supermarket or advise on the need to prioritise the intake of plant rather animal protein to 422 reduce the intake of products of animal origin, respectively. 


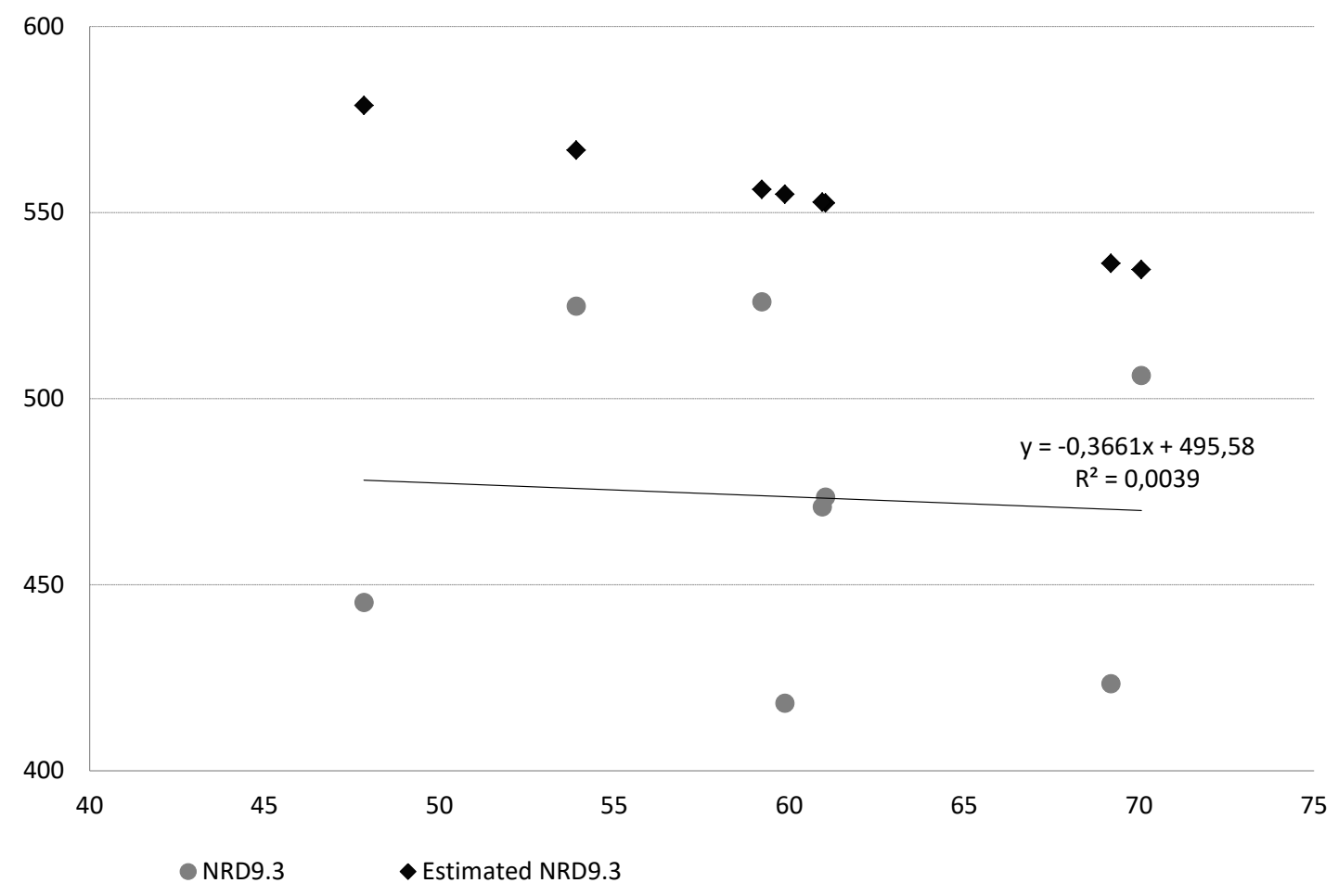

Figure 5. Correlation (grey marks) between NRD9.3 scores (y-axis) and AP\% (x-axis) for the weekly Atlantic diet designed for analysis. Marks in black have been estimated considering the correlation established by Van Kernebeek et al. (2014) and the AP\% values of our daily diets.

Finally, the nutritional quality of the diets has been completed with the estimation of individual nutrient-rich indexes to report dietary intake in relation to recommended daily values.

431 Table 5 summarizes the corresponding NR scores per daily diet. NR corresponding to protein, 432 fibre and potassium present a value of $100 \%$ since their intake exceeds the recommended 433 values. Magnesium intake also implies outstanding NR indexes, equal or very close to $100 \%$. In accordance with the methodology and in order to avoid credits for the overconsumption of nutrients to encourage, nutrient intake is assumed to be equal or greater than the RDV.

436 Conversely, values are not rounded to $100 \%$ for nutrients to limit if the recommended daily 437 value is exceeded. Nutrients to limit such as sodium and saturated fats generally present high 438 NR indexes (above 56 and 76\% respectively). In contrast, the intake of added sugar reports NR 439 indexes below 5\% regardless of the designed diet. These values are much lower than those of 440 other diets such as Mediterranean one (Castañé and Antón, 2017), where NR indexes of 441 between $80 \%$ and $136 \%$ can be expected. These high values are mainly related to the 442 consumption of products such as yoghurt and jam. 
444 and C (for Vitamin E below 3\% in most proposed daily menus). Improvements in this diet should

445 focus on promoting the intake of ingredients rich on both components, as they are nutrients to

446 encourage. Consumption of citrus products (e.g., orange, mandarin) and nuts (e.g. almonds,

447 hazelnuts) may contribute to increasing the NR-values for Vitamin C and Vitamin E,

448 respectively.

449

450 Table 5. Nutrient Rich (NR) score for each analysed nutrient. Scores have been calculated with 451 regard to the recommended daily value of each nutrient.

\begin{tabular}{|c|c|c|c|c|c|c|c|c|c|c|c|c|}
\hline & \multicolumn{9}{|c|}{ Boosting nutrients } & \multicolumn{3}{|c|}{ Limiting nutrients } \\
\hline & Protein & Fiber & VitA & VitC & VitE & $\mathrm{Ca}$ & $\mathrm{Fe}$ & $\mathbf{K}$ & Mg & $\begin{array}{c}\text { Saturated } \\
\text { fat }\end{array}$ & $\begin{array}{l}\text { Added } \\
\text { sugar }\end{array}$ & $\mathrm{Na}$ \\
\hline Monday & 100 & 100 & 91.5 & 32.9 & 2.1 & 82.1 & 100 & 100 & 100 & 121 & 3.8 & 77.5 \\
\hline Tuesday & 100 & 100 & 34.3 & 19.7 & 2.3 & 48.5 & 65.9 & 100 & 100 & 71.7 & 4.6 & 76.3 \\
\hline Wednesday & 100 & 100 & 39.7 & 24.3 & 1.9 & 63.1 & 65.5 & 100 & 100 & 99.4 & 3.6 & 68.1 \\
\hline Thursday & 100 & 100 & 87.0 & 44.9 & 2.6 & 65.8 & 100 & 100 & 100 & 94.1 & 4.6 & 76.8 \\
\hline Friday & 100 & 100 & 100 & 38.0 & 2.3 & 63.6 & 61.0 & 100 & 100 & 75.9 & 2.9 & 56.3 \\
\hline Saturday & 100 & 100 & 90.8 & $3^{\circ} 0.0$ & 2.2 & 57.7 & 53.2 & 100 & 86.3 & 90.5 & 4.6 & 80.0 \\
\hline Sunday & 100 & 100 & 90.8 & 28.0 & 18.1 & 52.7 & 55.6 & 100 & 98.2 & 94.0 & 3.8 & 74.7 \\
\hline Daily average & 100 & 100 & 76.3 & 31.1 & 4.5 & 61.9 & 71.6 & 100 & 97.8 & 93.3 & 4.1 & 74.3 \\
\hline
\end{tabular}

\section{2}

454 3.2.1. Detailed analysis of carbon footprint for the designed menus

455 The estimation of GHG emissions (i.e., carbon footprint) corresponding to the menus 456 designed following the recommendations of the Atlantic diet represents an absolute value of $45721.04 \mathrm{~kg} \mathrm{CO}_{2}$ eq per person and week, i.e., an average of $3.01 \mathrm{~kg} \mathrm{CO}_{2}$ eq. person ${ }^{-1}$. day ${ }^{-1}$. This

458 value is slightly higher $(\sim 5 \%)$ than that reported in the literature focusing on the assessment of 459 the Mediterranean dietary pattern, the most widespread diet in Spain (Castañé and Antón, 460 2017; Muñoz et al., 2010) and with characteristics similar to those of the Atlantic. The rationale 461 behind that difference is mostly associated with differences on the dietary patterns as well as 462 with the consideration of refrigeration process at households within the system boundaries, 463 which was excluded from analysis by Castañé and Antón (2017) and which adds to $0.23 \mathrm{~kg}$ 
$\mathrm{CO}_{2}$ eq. person ${ }^{-1}$. day ${ }^{-1}$. Considering the same system boundaries, the $\mathrm{AD}$ presents a carbon 465 footprint around $8 \%$ lower than the corresponding to the Mediterranean one $(2.86 \mathrm{~kg}$ $466 \mathrm{CO}_{2}$ eq.person ${ }^{-1} \cdot$ day $^{-1}$ ). The shift towards consumption of fish and fresh products (seasonal food) with limited cooking is behind this difference.

Through a more detailed assessment of the factors responsible for the carbon footprint of the $A D$, the production of the different food products is identified as a hot spot followed by household (cooking and refrigeration) and transport activities. Contributions from the production stage account for approximately $78 \%$ of total GHG emissions, with the remaining $22 \%$ is split between the household stage (92\%) and transport activities (8\%). Figure 6 displays the carbon footprint per day, as well as the distribution between the stages included in the analysis (food production, household and transport).

475

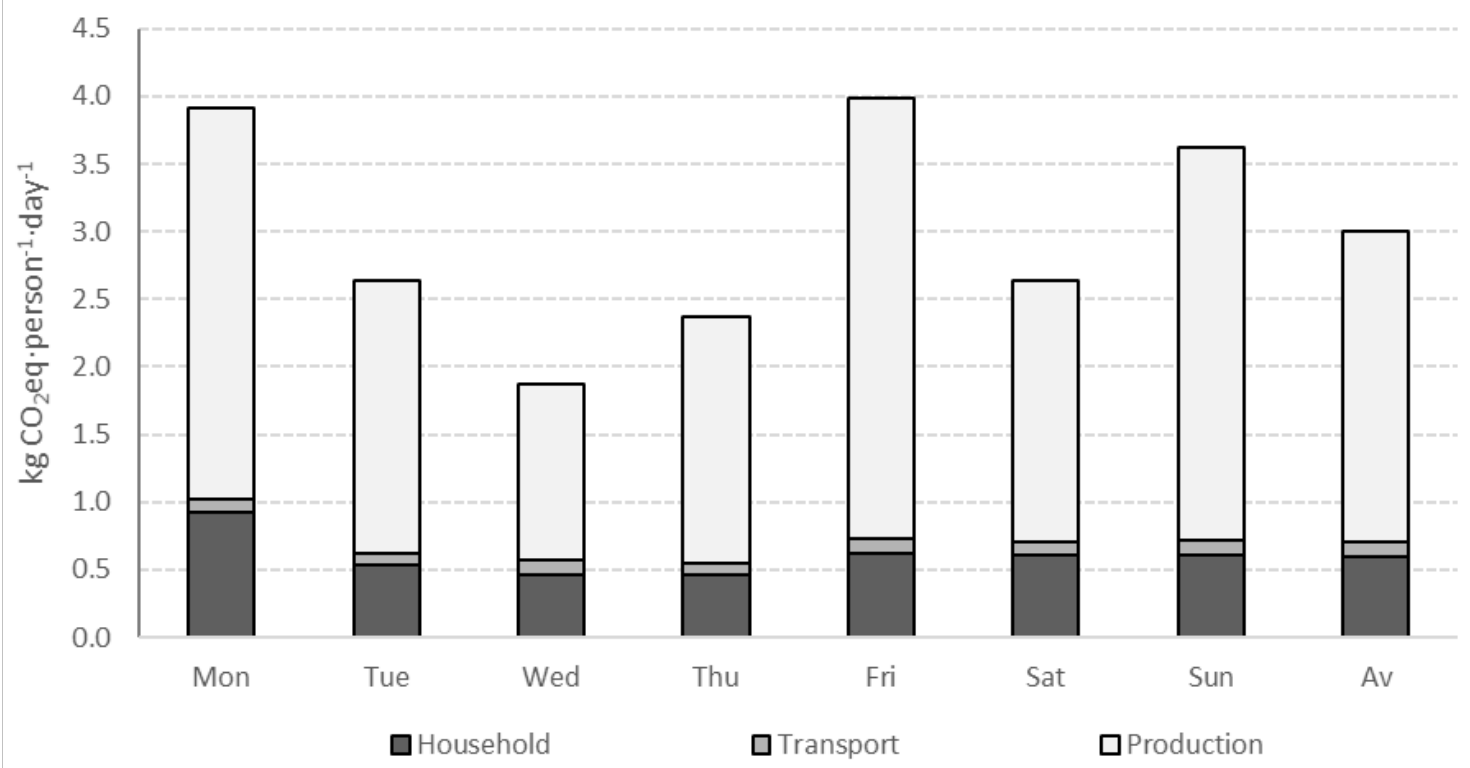

477 Figure 6. Daily carbon footprint (in $\mathrm{kg} \mathrm{CO}_{2} \mathrm{eq} \cdot$ person $^{-1} \cdot$ day $^{-1}$ ) taking into account the distribution between food production, transport and household stages.

Regarding the stage of food production (with an average of $2.31 \mathrm{~kg} \mathrm{CO} \mathrm{Cq}_{2} \cdot$ person $^{-1} \cdot$ day $^{-1}$ ), it includes all the background activities carried out in the field and on the farm as well as the corresponding industrial processing, if necessary. According to Figure 7, meat and dairy production (livestock-based items) is primarily responsible for GHG emissions at this stage

484 (26\% and 30\%, respectively). Moreover, both food categories are primarily responsible for 
variations in the carbon footprint between different daily diets. Looking more closely at the contribution of meat production, red meat accounts for $23 \%$, followed by white meat $(1.6 \%$ pork and $1.4 \%$ chicken, respectively).

In contrast, vegetables and fruits are low-carbon food categories (see Table 1 of SM) but consumed in major shares in the Atlantic diet. Therefore, both categories report contributions of $8 \%$ of total GHG emissions from the food production stage.

491

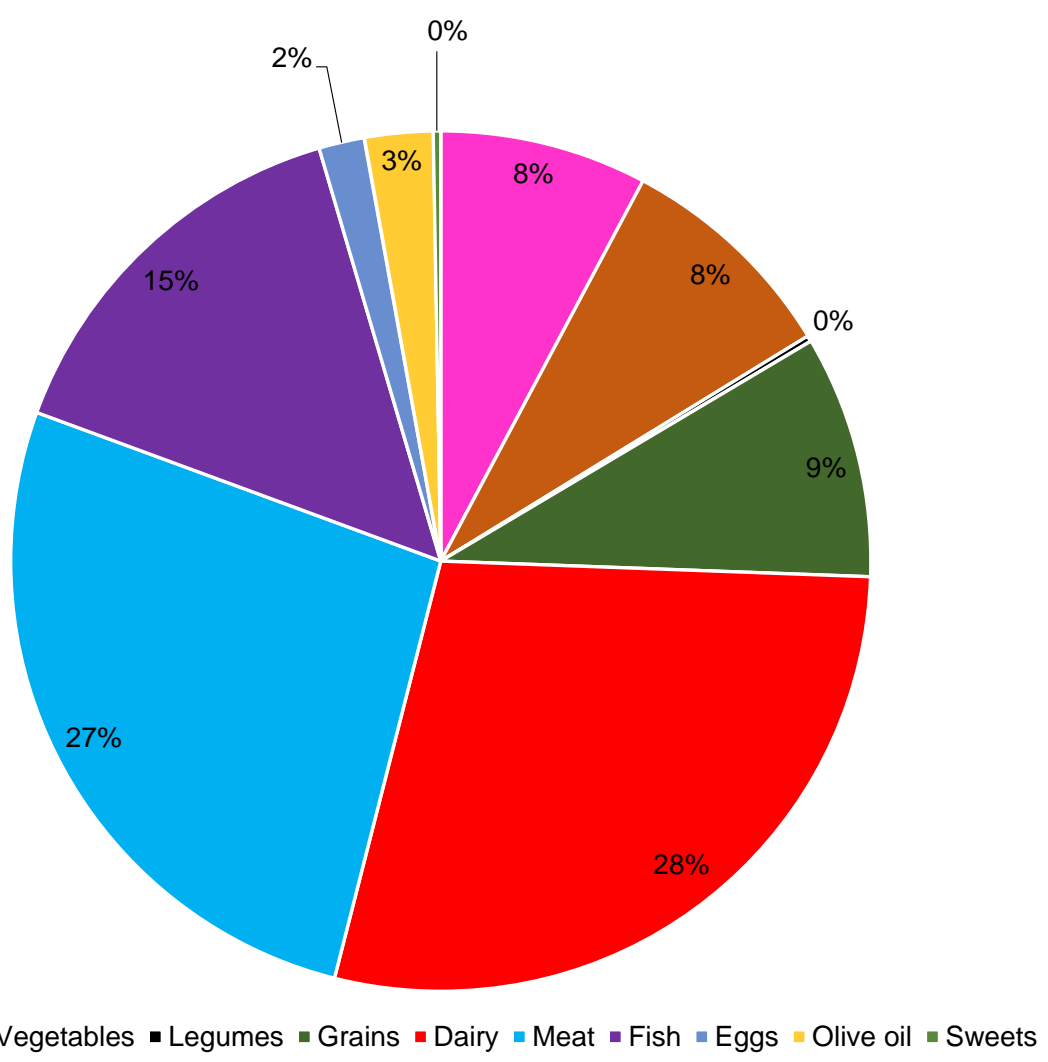

493 Figure 7. Relative distribution of GHGs emission from food production stage between the food groups involved in the designed 7-day menu.

The remarkable effect on the carbon footprint of livestock products has been highlighted by 497 numerous studies, including those focusing on very different dietary patterns such as Spanish, 498 Peruvian, Western European, American, British and French (Castañé and Antón, 2017; Coelho 499 et al., 2016; Muñoz et al., 2010; Pimentel and Pimentel, 2003; Sáez-Almendros et al., 2013; 500 Scarborough et al., 2014; Vázquez-Rowe et al., 2017). Both products are an important source of protein and energy, and their production involves resource-intensive activities (e.g., fodder 
502 production and agricultural activities), as well as methane emissions from rumiant enteric 503 fermentation.

504 The seafood category has an outstanding contribution (15\% of the total). This contribution is 505 directly related to the remarkable consumption of fish in the Atlantic diet (Vaz Velho et al., 2016)

506 despite reporting moderate rate of GHG emissions per kg of product (see Table 1 of SM). Grain 507 products such as cereals and bread are basic products of the Atlantic food pyramid and their 508 contributing ratio rises to $9 \%$.

509 In terms of GHG emissions from household activities, the total energy required for the 7-day 510 menu is about $33 \mathrm{MJ}$ per week and person split between cooking (60\%) and refrigeration (40\%).

511 Energy consumption in cooking activities is slightly lower than that of Castañé and Antón 512 (2017), i.e., $30 \mathrm{MJ}$ for the Mediterranean diet. In this sense, the abundance of fresh food 513 products in the Atlantic diet makes complex cooking processes unnecessary, and therefore, 514 implies low energy requirements for cooking. Taking into account the distribution of the carbon 515 footprint among the contributing stages (see Figure 6), there are no significant differences in the 516 average energy consumption for household activities regardless of the designed daily diet, as 517 shown in Figure 6. The consideration of only boiling, frying and baking as the main cooking 518 processes in the analysis -as recommended by the Atlantic diet- is also responsible for these 519 negligible differences between the daily menus with regard to the household stage. Boiling and 520 frying (the most common daily cooking methods) report similar energy requirements $(\sim 0.75 \mathrm{MJ}$ 521 per meal and person, on average). For baking, it is considerably higher, about $4.1 \mathrm{MJ}$ per meal 522 and person.

523 Finally, the contribution of the transport stage to the global carbon footprint can be 524 considered negligible since it represents less than $2 \%$ of the total (on average) with $0.70 \mathrm{~kg}$ $525 \mathrm{CO}_{2}$ eq. week $^{-1}$. person ${ }^{-1}$. As far as the origin of food is concerned, Galician products have the 526 lowest GHG emissions due to the shorter distribution distances by lorry. Products of foreign 527 origin are distributed by sea freighter and/or lorry. Maritime transportation does not report 528 outstanding contributions to the carbon footprint despite long distances. Once again, road 529 transport is the main contributing factor to the carbon footprint (five times more than maritime 530 transport). 
Numerous studies available in the literature were developed with regard to the

534 environmental assessment of human diets where special attention was paid to the estimation of

535 the carbon footprint (Castañé and Antón, 2017; Coelho et al., 2016; Notarnicola et al., 2017;

536 Pairotti et al., 2015; Pernollet et al., 2017; Röös et al., 2015; Saxe et al., 2012; Scarborough et

537 al., 2014; Vázquez-Rowe et al., 2017). All these studies highlight the limitations of the analysis

538 in the absence of an established methodology and data. The focus on the carbon footprint is

539 based on the availability of data and the awareness of society to avoid anthropogenic GHG

540 emissions to prevent climate change (Rockström et al., 2009). The comparison between our

541 results for the Atlantic diet and those available in the literature for other types of dietary patterns

542 (e.g., Mediterranean, average European, average Spanish, German, Swedish, French, vegan,

543 vegetarian, Nordic, among others) is complex because the results depend on a wide variety of

544 factors and hypotheses.

545 The number of calories that an average person needs on a daily basis depends on several

546 factors, such as minimum and average dietary energy requirements (Vázquez-Rowe et al.,

547 2017), level of activity, gender, age, weight, geographical location and cultural aspects (EFSA,

548 2009). Therefore, the range of energy requirements per capita identified in the literature varies

549 from $1,702 \mathrm{kcal} \cdot$ person $^{-1}$. day ${ }^{-1}$ in Indian diets (Pathak et al., 2010) to 3,596 kcal.person ${ }^{-1}$. day ${ }^{-1}$

550 in Western European countries (Tukker et al., 2011). The daily energy intake recommended by

551 the Panel on Dietetic Products, Nutrition and Allergies (EFSA, 2009) is 2,000 kcal. person-1. day-

552 1.in European countries. It falls in half the range for a moderately active woman $(1,625-2,400$

$553 \mathrm{kcal} \cdot \mathrm{person}^{-1} \cdot \mathrm{day}^{-1}$ ), which is consistent with the values recommended in other countries such

554 as the United States, Australia and New Zealand, as well as by the European food industry

555 (EFSA, 2009). According to experts, this value $\left(2,000 \mathrm{kcal}^{\text {person }}{ }^{-1} \cdot \mathrm{day}^{-1}\right)$ is more consistent

556 with dietary advice for the general population compared to men (2,200-2,300 kcal.person-1. day

$\left.557{ }^{1}\right)$. Therefore, the value set in our study $\left(2,100 \mathrm{kcal} \cdot\right.$ person $\left.^{-1} \cdot \mathrm{day}^{-1}\right)$ could be considered

558 representative for the assessment and coincides with other relevant studies available in the

559 literature (Castañé and Antón, 2017; Collins and Fairchild, 2007; Peters et al., 2007; Sáez-

560 Almendros et al., 2013; Scarborough et al., 2014). 
Therefore, in order to compare the carbon footprints of different dietary scenarios or patterns, the results should be expressed on the basis of the so-called functional unit, in this case, the average energy requirement per person and day. Thus, only the isocaloric diets available in the literature in the range of 2,000-2,100 kcal. person ${ }^{-1}$. day ${ }^{-1}$ have been considered for comparative analysis of the carbon footprint. This range can be assumed since diets use realistic amounts of food (see Table 1) and it is complex to fix the energy to an identical number.

Consideration of that unit can be used to estimate the change in GHG emissions that would result from changing dietary patterns without modifying the dietary energy intake, which should be more relevant when considering the potential impact of dietary change diets on GHG emissions. According to the CF values depicted in Figure 8, the results obtained for the Atlantic diet (Scenarios A and A1-A7) of $3.01 \mathrm{~kg} \mathrm{CO}_{2}$ eq. person $^{-1}$. day ${ }^{-1}$ (on average) are comparable to the values found in other studies focusing on the estimation of this environmental impact for Spanish diets such as Castañé and Antón (2017) (Scenarios B and C) and Sáez-Almendros et al. (2013), who reported about 2.86 and $2.19 \mathrm{~kg} \mathrm{CO}$ eq. person ${ }^{-1}$. day ${ }^{-1}$, respectively, for the Mediterranean dietary pattern. Both types of diets are conceived as healthy and are essentially very similar. However, there are two remarkable differences between them, namely: i) the promotion of fish as the main foodstuff ${ }^{2}$ and ii) the high intake of red meat and pork in the Atlantic one. However, attention must be paid to the system boundaries. Sáez-Almendros et al. (2013) considered the same system boundaries as in our study but excluding only refrigeration at households. However, Castañé and Antón (2017) excluded not only home storage but also retailing from the analysis as they considered it irrelevant to global GHGs emissions.

The results of the Atlantic diet are not similar to those reported by Sáez-Almendros et al. 584 (2013) for the current Spanish diets, based on food balances and consumption surveys 585 (Scenarios $\mathrm{E}$ and $\mathrm{F}, 7.76$ and $4.39 \mathrm{~kg} \mathrm{CO} 2$ eq. person ${ }^{-1}$. day ${ }^{-1}$ respectively). These remarkable 586 results are directly related to the source of information considered for the estimation of the 587 carbon footprint. In both cases, diets were based on food consumption/purchase data and not 588 on recommended intake values. Regarding the scenario considering the typical Western dietary 589 pattern (Scenario G), the worst environmental outcomes were reported. Consideration and

\footnotetext{
${ }^{2}$ http://www.fundaciondiabetes.org/
} 
590 promotion of the Atlantic diet would substantially reduce GHG emissions by up to 4.5 times.

591 Excessive consumption of animal products, such as meat and dairy products, is primarily

592 responsible for contributions to GHG emissions due to the high impact of livestock production.

593 The Western dietary pattern is characterised by the outstanding presence of meat and dairy

594 products, up to 8 and 4 times -respectively, higher than in other dietary patterns such as the

595 Mediterranean one (Sáez-Almendros et al., 2013).

596

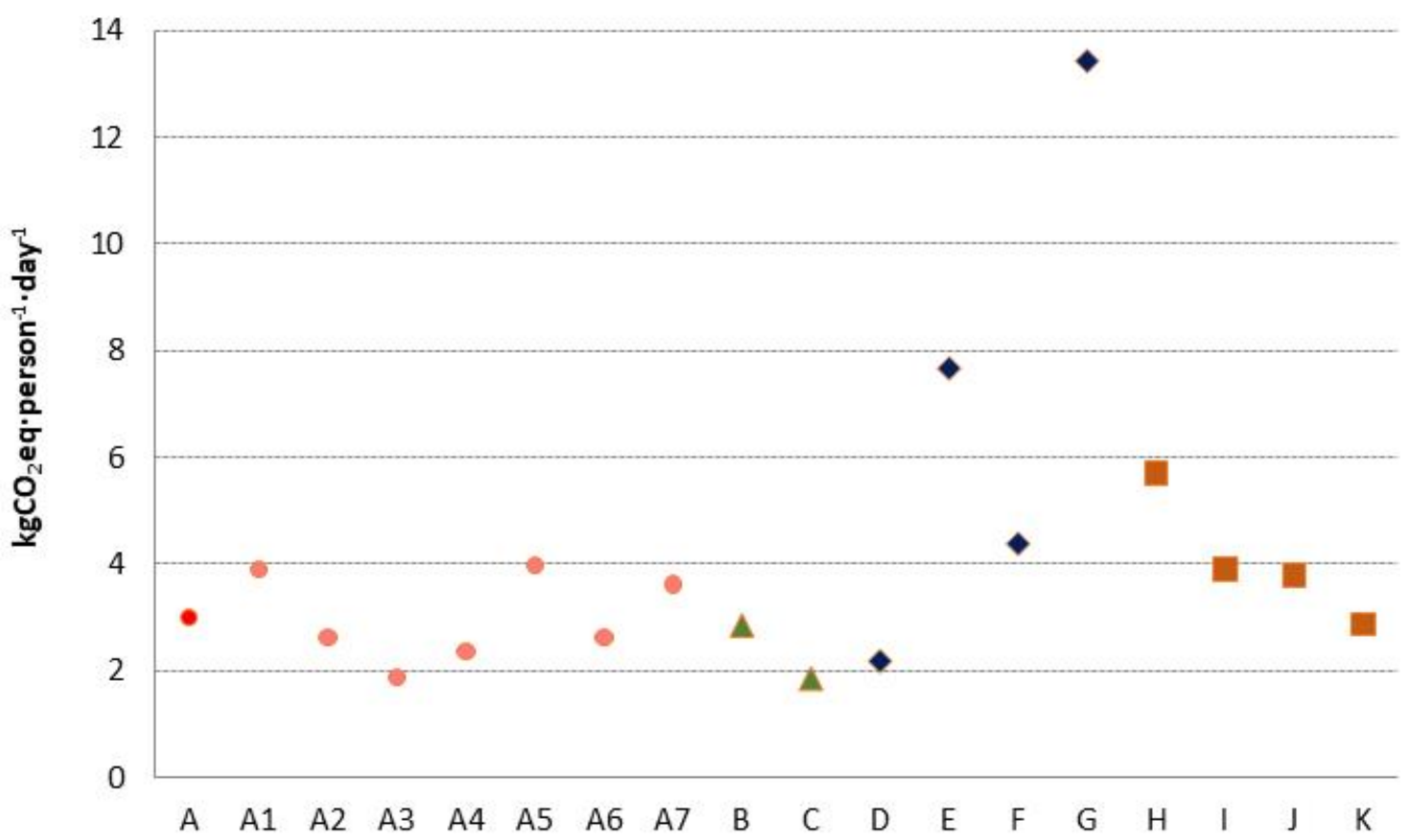

Figure 8. Carbon footprint scores for the different diet scenarios considered for comparison.

599 Acronyms: A - average Atlantic diet; A1-A7 - designed daily Atlantic diets; B and C from

600 Castañé and Antón (2017); D, E, F and G from Sáez-Almendros et al. (2013); H, I, J and K from

601 Scarborough et al. (2014).

602

603

For the values proposed by Scarborough et al. (2014), the meat-rich diet reported the worst

604 carbon footprint score. Fish-rich and vegetarian diets reported similar scores (3.90 and 3.80

605 $\mathrm{kgCO}_{2}$ eq. person ${ }^{-1} \cdot$ day $\left.^{-1}\right)$. The vegan diet score is closing similar to those for the Atlantic and

606 Mediterranean diets. Therefore, according to scientific literature, the presence of food products

607 of animal origin in the dietary pattern contributes significantly to increasing GHG emissions,

608 which demonstrates the positive relationship between dietary CF and the ratio of animal based 609 products. 
611 definition. In our estimation, household stage includes not only cooking but also refrigeration.

612 Several studies available in the literature remark the outstanding contribution from energy use in

613 household storage to the global carbon footprint of a dietary choice (Berlin and Sund, 2010;

614 Heller et al., 2013; Muñoz et al., 2010; Sáez-Almendros et al., 2013). However, other authors

615 (Castañé and Antón, 2017), excluded this cold storage from analysis. According to our results,

616 refrigeration at household is close to $10 \%$ (in average), being an important hot spot in the

617 carbon footprint. The exclusion of this factor from the system boundaries should derive into an

618 average carbon footprint of $2.78 \mathrm{kgCO}_{2} \mathrm{eq} \cdot$ person $^{-1}$. day ${ }^{-1}$ for the Atlantic diet being this value

619 under the one estimated for the Mediterranean diet by Castañé and Antón (2017). Regarding

620 data quality, the way in which foodstuffs are produced, cultivated or farmed potentially affects

621 GHG emission (González-García et al., 2018). Thus, the definition of both system boundaries

622 and food production strategies are issue which require special attention mostly if the carbon

623 footprint profiles are going to be compared between dietary choices as well as in decision

624 making strategies

625 As final recommendations to moving dietary patterns towards more environmentally

626 sustainable ones, the following actions should be taken into consideration:

627 - Promote the reduction of meat and dairy products by increasing consumption of plant

628 based products

629 - Promote the consumption of local and seasonal products, which should lead to a

630 reduction in transport activities and management, respectively

631 - Reduction of red meat intake by consuming white meat such as chicken and pork

632 - Social campaign (cultural training, special taxes for ecologic products, ...) to promote

633 the benefits of environmental sustainable diets.

634

635 4. Conclusions

636 According to the main findings reported in this study, the Atlantic diet can be considered 637 beneficial not only from a health, but also from an environmental perspective due to the 638 significant consumption of fish and plant based products compared to other dietary patterns 639 richer on livestock products. Moreover, the characteristics of the Atlantic diet, based on 
640 promoting the consumption of seasonal, fresh and local products, home-made cooking and lowprocessed foods also contribute to its low carbon footprint. In this sense, it can be considered

642 as a sustainable diet as defined by $\mathrm{FAO}$, since it has a low environmental impact and contributes to food safety and quality (FAO, 2010).

In terms of contributions to the carbon footprint, the food production stage is primarily responsible for GHG emissions, followed by the cooking stage and transport activities. Meat, dairy and fish products have the highest individual footprint, especially cheese and beef, although their quantities consumed are not as important as other foods such as vegetables or fruits, which are considered basic foods in the recommended Atlantic diet. With regard to the nutritional quality, daily diets with higher NRD9.3 scores should be promoted since they are linked to lower intake of total protein and animal based products. According to our results, daily diets with higher values of AP are associated with higher GHGs emissions. In this way, the possibility of a change in the direction of a lower consumption of animal protein is related with more sustainable diets, as mentioned in several studies in many countries (Perignon et al., 654 2016).

655 The total carbon footprint of the diet could be reduced by minimizing the intake of livestock 656 products in agreement with other studies. Thus, even though the ingested quantities of meat and dairy products are not very high in the Atlantic pattern, they could still be reduced, being compensated for by the intake of plant origin protein. The increase in the nutritional quality together with the improvement of the carbon footprint associated to the shift of protein intake from animal to vegetable origin needs to be analysed in more detail.

Although this study focuses on outlining a designed Atlantic diet, following recommendations, future researches should take into account the current consumption trends of the region, with the same purpose of linking the environmental and nutritional quality, but under real consumption conditions, which could be compared with the results from this study. In addition, it would be interesting to include socioeconomic variables, relating them to those mentioned above. 
669 could be considered as a strategic solution to promote sustainable food consumption, but 670 comprehensive educational programs must be developed.

671

672

673

674 Acknowledgements

675 This research has been supported by a project granted by Xunta de Galicia (project ref. 676 ED431F 2016/001). Dr. S. González-Garcia would like to express her gratitude to the Spanish 677 Ministry of Economy and Competitiveness for financial support (Grant reference RYC-2014678 14984). The authors belong to the Galician Competitive Research Group GRC 2013-032 as well 679 as to CRETUS (AGRUP2015/02), co-funded by Xunta de Galicia and FEDER (EU).

680 
Aguilera, E., Guzmán, G., Alonso, A., 2015. Greenhouse gas emissions from conventional and organic cropping systems in Spain. II. Fruit tree orchards. Agron. Sustain. Dev. 35, 725737. doi:10.1007/s13593-014-0265-y

Aleksandrowicz, L., Green, R., Joy, E.J.M., Smith, P., Haines, A., 2016. The Impacts of Dietary Change on Greenhouse Gas Emissions, Land Use, Water Use, and Health: A Systematic Review. PLoS One 11, e0165797. doi:10.1371/journal.pone.0165797

Andersson, K., Ohlsson, T., 1999. Life cycle assessment of bread produced on different scales. Int. J. Life Cycle Assess. 4, 25-40. doi:10.1007/BF02979392

Andersson, K., Ohlsson, T., Olsson, P., 1998. Screening Life Cycle Assessment (LCA) of tomato ketchup: A case study. Doktorsavhandlingar vid Chalmers Tek. Hogsk. 6, 1-19. doi:10.1016/S0959-6526(98)00027-4

Baroni, L., Cenci, L., Tettamanti, M., Berati, M., 2007. Evaluating the environmental impact of various dietary patterns combined with different food production systems. Eur. J. Clin. Nutr. 61, 279-286. doi:10.1038/sj.ejcn.1602522

Berlin, J., 2002. Environmental life cycle assessment (LCA) of Swedish semi-hard cheese. Int. Dairy J. 12, 939-953. doi:10.1016/S0958-6946(02)00112-7

Berlin, J., Sund, V., 2010. Environmental life cycle assessment (LCA) of ready meals: LCA of two meals; pork and chicken \& screening assessments of six ready meals, SIK Rapport.

Calvo-Malvar, M. del M., Leis, R., Benítez-Estévez, A.J., Sánchez-Castro, J., Gude, F., 2016. A randomised, family-focused dietary intervention to evaluate the Atlantic diet: the GALIAT study protocol. BMC Public Health 16, 820. doi:10.1186/s12889-016-3441-y

Carlsson-Kanyama, A., Faist, M., 2000. Energy Use in the Food Sector: A data survey 36.

Carlsson-Kanyama, A., González, A.D., 2009. Potential contributions of food consumption doi:10.3945/ajen.2009.26736AA.1704S

Castañé, S., Antón, A., 2017. Assessment of the nutritional quality and environmental impact of two food diets: A Mediterranean and a vegan diet. J. Clean. Prod. 167, 929-937.

710 Cencic, A., Chingwaru, W., 2010. The role of functional foods, nutraceuticals, and food 
supplements in intestinal health. Nutrients 2, 611-625. doi:10.3390/nu2060611

712 Coelho, C.R. V, Pernollet, F., van der Werf, H.M.G., 2016. Environmental Life Cycle

713 Assessment of Diets with Improved Omega-3 Fatty Acid Profiles. PLoS One 11,

$714 \quad$ e0160397. doi:10.1371/journal.pone.0160397

715 Collins, A., Fairchild, R., 2007. Sustainable food consumption at a sub-national level: An

716 ecological footprint, nutritional and economic analysis. J. Environ. Policy Plan. 9, 5-30.

717 doi:10.1080/15239080701254875

718 Committee on Climate Change, 2010. The fourth carbon budget: reducing the emissions

719 through 2020.

720 Donati, M., Menozzi, D., Zighetti, C., Rosi, A., Zinetti, A., Scazzina, F., 2016. Towards a

721 sustainable diet combining economic, environmental and nutritional objectives. Appetite

$722 \quad$ 106, 48-57. doi:10.1016/j.appet.2016.02.151

723 Drewnowski, A., 2009. Defining nutrient density: Development and validation of the nutrient rich

724 foods index. J. Am. Coll. Nutr. 28, 421S-426S. doi:10.1080/07315724.2009.10718106

725 Duchin, F., 2005. Sustainable Consumption of Food - A Framework for Analyzing Scenarios

726 about Changes in Diets. J. Ind. Ecol. 9, 99-114. doi:10.1162/1088198054084707

727 EFSA, 2009. Review of labelling reference intake values Scientific Opinion of the Panel on

728 Dietetic Products, Nutrition and Allergies on a request from the Commission related to the

729 review of labelling reference intake values for selected nutritional elements 1 Adop.

730 FAO, 2014. Necesidades Nutricionales del Ser Humano, FAO.

731 FAO, 2010. Biodiversity and sustainable diets united against hunger. Rome.

732 Fulgoni, V.L., Keast, D.R., Drewnowski, A., 2009. Development and Validation of the Nutrient-

733 Rich Foods Index: A Tool to Measure Nutritional Quality of Foods. J. Nutr. 139, 1549-

$734 \quad$ 1554. doi:10.3945/jn.108.101360

735 Fundación Española de la Nutrición, 2004. Consumo de alimentos en Galicia. La dieta atlántica.

$736 \quad$ Madrid.

737 Garnett, T., 2011. Where are the best opportunities for reducing greenhouse gas emissions in

738 the food system (including the food chain)? Food Policy 37, 463-466.

739 doi:10.1016/j.foodpol.2012.04.006

740 Gerbens-Leenes, P., Nonhebel, S., Ivens, W., 2002. A method to determine land requirements 
relating to food consumption patternsA method to determine land requirements relating to food consumption patterns. Agric. Ecosyst. Environ. 90, 47-58.

743 Gerbens-Leenes, P.W., Nonhebel, S., 2002. Consumption patterns and their effects on land required for food $42,185-199$.

Goldstein, B., Hansen, S.F., Gjerris, M., Laurent, A., Birkved, M., 2016. Ethical aspects of life cycle assessments of diets. Food Policy 59, 139-151. doi:10.1016/j.foodpol.2016.01.006

González-García, S., Castanheira, É.G., Dias, A.C., Arroja, L., 2013a. Environmental life cycle assessment of a dairy product: The yoghurt. Int. J. Life Cycle Assess. 18, 796-811. doi:10.1007/s11367-012-0522-8

González-García, S., Hospido, A., Moreira, M.T., Feijoo, G., Arroja, L., 2013b. Environmental life cycle assessment of a galician cheese: San Simon da Costa. J. Clean. Prod. 52, 253262. doi:10.1016/j.jclepro.2013.03.006

González, A.D., Frostell, B., Carlsson-Kanyama, A., 2011. Protein efficiency per unit energy and per unit greenhouse gas emissions: Potential contribution of diet choices to climate change mitigation. Food Policy 36, 562-570. doi:10.1016/j.foodpol.2011.07.003

Hallström, E., Carlsson-Kanyama, A., Börjesson, P., 2015. Environmental impact of dietary change: A systematic review. J. Clean. Prod. 91, 1-11. doi:10.1016/j.jclepro.2014.12.008 Heller, M.C., Keoleian, G.A., Willett, W.C., 2013. Toward a life cycle-based, diet-level framework for food environmental impact and nutritional quality assessment: a critical review. Env. Sci Technol 47, 12632-12647. doi:10.1021/es4025113

Hospido, A., Tyedmers, P., 2005. Life cycle environmental impacts of Spanish tuna fisheries. Fish. Res. 76, 174-186. doi:10.1016/j.fishres.2005.05.016

Irz, X., Leroy, P., Réquillart, V., Soler, L.G., 2016. Welfare and sustainability effects of dietary recommendations. Ecol. Econ. 130, 139-155. doi:10.1016/j.ecolecon.2016.06.025

ISO 14040, 2006. Environmental management — Life cycle assessment — Principles and framework, Iso 14040. Switzerland. doi:10.1136/bmj.332.7550.1107 point of view investigated with a modular LCA. Int. J. Life Cycle Assess. 5, 134-142. doi:10.1007/BF02978609

Leiva, F.J., Saenz-Díez, J.C., Martínez, E., Jiménez, E., Blanco, J., 2015. Environmental impact 
of Agaricus bisporus cultivation process. Eur. J. Agron. 71, 141-148. doi:10.1016/j.eja.2015.09.013

Medrano, M.J., Boix, R., Palmera, A., Ramis, R., Galán, I., López-Abente, G., 2012. Towns with extremely low mortality due to ischemic heart disease in Spain. BMC Public Health 12 , 174. doi:10.1186/1471-2458-12-174

Muñoz, I., Milà I Canals, L., Fernández-Alba, A.R., 2010. Life cycle assessment of the average Spanish diet including human excretion. Int. J. Life Cycle Assess. 15, 794-805. doi:10.1007/s11367-010-0188-z

Nordström, K., Coff, C., Jönsson, H., Nordenfelt, L., Görman, U., 2013. Food and health: Individual, cultural, or scientific matters? Genes Nutr. 8, 357-363. doi:10.1007/s12263013-0336-8

Notarnicola, B., Tassielli, G., Renzulli, P.A., Castellani, V., Sala, S., 2017. Environmental impacts of food consumption in Europe. J. Clean. Prod. 140, 753-765. doi:10.1016/j.jclepro.2016.06.080

Noya, I., Villanueva-Rey, P., González-García, S., Fernandez, M.D., Rodriguez, M.R., Moreira, M.T., 2017. Life Cycle Assessment of pig production: A case study in Galicia. J. Clean. Prod. 142, 4327-4338. doi:10.1016/j.jclepro.2016.11.160

Pairotti, M.B., Cerutti, A.K., Martini, F., Vesce, E., Padovan, D., Beltramo, R., 2015. Energy consumption and GHG emission of the Mediterranean diet: A systemic assessment using a hybrid LCA-IO method. J. Clean. Prod. 103, 507-516. doi:10.1016/j.jclepro.2013.12.082

Pathak, H., Jain, N., Bhatia, A., Patel, J., Aggarwal, P.K., 2010. Carbon footprints of Indian food items. Agric. Ecosyst. Environ. 139, 66-73. doi:10.1016/j.agee.2010.07.002

Perignon, M., Masset, G., Ferrari, G., Barré, T., Vieux, F., Maillot, M., Amiot, M.J., Darmon, N., 2016. How low can dietary greenhouse gas emissions be reduced without impairing nutritional adequacy, affordability and acceptability of the diet? A modelling study to guide sustainable food choices. Public Health Nutr. 19, 2662-2674. doi:10.1017/S1368980016000653

Pernollet, F., Coelho, C.R.V., van der Werf, H.M.G., 2017. Methods to simplify diet and food life 800 cycle inventories: Accuracy versus data-collection resources. J. Clean. Prod. 140, 410420. doi:10.1016/j.jclepro.2016.06.111 
801

802

803

804

805

806

807

808

809

810

811

812

813

814

815

816

817

818

819

820

821

822

823

824

825

826

827

828

829

830

Peters, C.J., Wilkins, J.L., Fick, G.W., 2007. Testing a complete-diet model for estimating the land resource requirements of food consumption and agricultural carrying capacity: The New York State example. Renew. Agric. Food Syst. 22, 145-153. doi:10.1017/S1742170507001767

Pimentel, M., Pimentel, D., 2003. Sustainability of meat-based and plant based diets and the environment. Am. J. Clin. Nutr. 78(suppl), 660-663. doi:10.1177/0956247808089156

Risku-Norja, H., 2011. From environmental concerns towards sustainable food provisioning. Material flow and food consumption scenario studies on sustainability of agri-food systems.

Rockström, J., Steffen, W., Noone, K., Persson, Å., Chapin, F.S., Lambin, E., Lenton, T.M., Scheffer, M., Folke, C., Schellnhuber, H.J., Nykvist, B., de Wit, C.A., Hughes, T., van der Leeuw, S., Rodhe, H., Sörlin, S., Snyder, P.K., Costanza, R., Svedin, U., Falkenmark, M., Karlberg, L., Corell, R.W., Fabry, V.J., Hansen, J., Walker, B., Liverman, D., Richardson, K., Crutzen, P., Foley, J., 2009. Planetary boundaries: Exploring the safe operating space for humanity. Ecol. Soc. 14. doi:10.5751/ES-03180-140232

Röös, E., Karlsson, H., Witthöft, C., Sundberg, C., 2015. Evaluating the sustainability of dietscombining environmental and nutritional aspects. Environ. Sci. Policy 47, 157-166. doi:10.1016/j.envsci.2014.12.001

Sáez-Almendros, S., Obrador, B., Bach-Faig, A., Serra-Majem, L., 2013. Environmental footprints of Mediterranean versus Western dietary patterns: beyond the health benefits of the Mediterranean diet. Environ. Health 12, 118. doi:10.1186/1476-069X-12-118

Saxe, H., Larsen, T.M., Mogensen, L., 2012. The global warming potential of two healthy Nordic diets compared with the average Danish diet. Clim. Change 116, 249-262. doi:10.1007/s10584-012-0495-4

Scarborough, P., Appleby, P.N., Mizdrak, A., Briggs, A.D.M., Travis, R.C., Bradbury, K.E., Key, T.J., 2014. Dietary greenhouse gas emissions of meat-eaters, fish-eaters, vegetarians and vegans in the UK. Clim. Change 125, 179-192. doi:10.1007/s10584-014-1169-1

Smedman, A., Lindmark-Månsson, H., Drewnowski, A., Edman, A.K.M., 2010. Nutrient density of beverages in relation to climate impact. Food Nutr. Res. 54. doi:10.3402/fnr.v54i0.5170 Sonesson, U., Anteson, F., Davis, J., Sjödén, P.-O., 2005. Home transport and wastage: 

doi:10.1579/0044-7447-34.4.371

833 Sonesson, U., Janestad, H., Raaholt, B., 2003. Energy for Preparation and Storing of Food -

834 Models for calculation of energy use for cooking and cold storage in households.

835 Tojo, R., Leis, R., 2009. La Dieta Atlántica, el pescado y las algas - Su importancia en el

836 neurodesarrollo y la función cerebral. Chapter: El papel de la Dieta Atlántica como

837 contrapunto saludable a la Dieta Ocidental actual. Universidad de Santiago de

$838 \quad$ Compostela.

839 Tukker, A., Goldbohm, R.A., De Koning, A., Verheijden, M., Kleijn, R., Wolf, O., Pérez-

840 Domínguez, I., Rueda-Cantuche, J.M., 2011. Environmental impacts of changes to

841 healthier diets in Europe. Ecol. Econ. 70, 1776-1788. doi:10.1016/j.ecolecon.2011.05.001

842 van de Kamp, M.E., van Dooren, C., Hollander, A., Geurts, M., Brink, E.J., van Rossum, C.,

843 Biesbroek, S., de Valk, E., Toxopeus, I.B., Temme, E.H.M., 2018. Healthy diets with

844 reduced environmental impact? - The greenhouse gas emissions of various diets adhering

845 to the Dutch food based dietary guidelines. Food Res. Int. 0-1.

846 doi:10.1016/j.foodres.2017.06.006

847 Van Der Werf, H.M.G., Salou, T., 2015. Economic value as a functional unit for environmental

848 labelling of food and other consumer products. J. Clean. Prod. 94, 394-397.

849 doi:10.1016/j.jclepro.2015.01.077

850 Van Kernebeek, H.R.J., Oosting, S.J., Feskens, E.J.M., Gerber, P.J., De Boer, I.J.M., 2014. The

851 effect of nutritional quality on comparing environmental impacts of human diets. J. Clean.

852 Prod. 73, 88-99. doi:10.1016/j.jclepro.2013.11.028

853 Vaz Velho, M., Pinheiro, R., Sofia, A., 2016. The Atlantic Diet - Origin and features. Int. J. Food

$854 \quad$ Stud. 5, 106-119. doi:10.7455/ijfs/5.1.2016.a10

855 Vázquez-Rowe, I., Larrea-gallegos, G., Villanueva-rey, P., Gilardino, A., 2017. Climate change

856 mitigation opportunities based on carbon footprint estimates of dietary patterns in Peru 1-

857 25. doi:10.1371/journal.pone.0188182

858 Xunta de Galicia, 2013. Menús saludables ricos en fibra. Santiago de Compostela.

859 Ziegler, F., Nilsson, P., Walther, B.M.Y., 2003. Life Cycle assessment of frozen cod fillets

860 including fishery-specific environmental impacts. Int. J. Life Cycle Assess. 8, 39-47. 
861 doi:10.1007/BF02978747

862 